\title{
U.S. FDI in Europe since 1990: An Empirical Investigation
}

\author{
Lidiya Tsurkanu, Hadley Leavell, and Balasundram Maniam
}

\begin{abstract}
The flow of FDI throughout the world has transformed since the 1990s. A dataset encompassing information from 1990 to 2008 was used to provide this paper's background for the study of U.S. FDI into the EU. The countries selected for the study are France, Germany, the Netherlands, Spain, and the United Kingdom. The economic results for this research paper have been obtained through various literature analyses, and then tested through multiple regression analyses. Using the results from the comprehensive model, this paper will examine the factors that affect U.S. foreign direct investments for the countries in the $\mathbf{E U}$.
\end{abstract}

Index Terms-Foreign direct investment, European Union, U.S. FDI, multiple analysis.

\section{INTRODUCTION}

The United States is a key source of foreign direct investments globally. The establishment of free trade agreements, such as NAFTA (North American Free Trade) and AFTA (ASEAN free trade), has allowed countries to do business and invest with more confidence and ease. The United States has demonstrated an increased interest in investing in foreign countries, both developing and developed. Foreign direct investments have provided economic benefits such as increased competition, technological spillovers, innovations, and increased employment to the host countries. These benefits explain why foreign countries have relaxed their investment policies and introduced new ones in order to attract inflows of foreign direct investments.

The nature of an individual subsidiary, the specific pattern of economic and social effects by a foreign subsidiary on its local surroundings and the economic-political conditions prevailing in the host country all factor into the FDI decisions. Free trade opened doors to new markets and helped expand domestic business in foreign countries. Foreign direct investments give developed countries the ability to expand their shares in the marketplace. In the developed countries, the increase in FDI inflows resulted in rapid economic growth and social development.

When trapped in a saturated market, a company should look for an alternative to sell its products in foreign countries. Foreign direct investments are considered a key player in the marketplace. This paper will examine foreign direct investment in the EU region from 1990 up to 2008 using the

Manuscript received March 2, 2015; revised May 26, 2015

The authors are with Sam Houston State University, Huntsville, TX 77341, USA (email: gba_bxm@shsu.edu, leavell@shsu.edu, maniam@shsu.edu) following countries in the sample: France, Germany, the Netherlands, Spain, and the United Kingdom.

\section{LITERATURE REVIEW}

Due to the growing financial and political significance of FDI, great quantities of literature can be found on that topic. Much of the literature covers topics on aspects of FDI such as impact on the society, advantages/disadvantages, the opportunities for FDIs in foreign countries, effects of FDI on the U.S. economy, the relationship between the government of the host country and the FDIs.

Reference [1] gives a broad review of the FDI and multinational corporations that exist in our global economy. The book focuses on exploring the nature and diversity of international businesses and the effects of FDI on the domestic economies and the international economic order. Reference [1] uses different levels of analysis to look at the nature of the international economic order, in particular FDI's and multinational corporation's (MNC's) role.

Reference [2] focuses on the relationship between FDI and inflation with a focus on the determinants of FDI that cause the increased volume of FDI flow. The author examines the vertical and horizontal FDI (VFDI and HFDI, respectively) and compares VFDI and HFDI. Also, the article focuses on the investment-smoothing technique multinational enterprises (MNEs) use to shift investments between home and host countries in order to minimize the negative impact of the changes in the macroeconomic environment. Reference [2] submits that foreign direct investments are used as a hedging tool to mitigate the effects of inflation taxes.

Reference [3] reviews literature published after the 1997 Asian crisis on FDI on host country government policies toward FDIs, with a main concentration on FDI incentives. Ruane discusses the tests smaller host economies and their governments face in their efforts to attract FDI and points out the opportunities and challenges that arise from attracting foreign direct investments in order to realize economic goals.

Reference [4] explores the relationship between MNE current strategies and economic development Reference [4] focuses on the positive developmental impact FDI flows have on the host country, FDIs conditional dependence on high levels of human capital and good infrastructure, and FDIs help in improving economic development and poverty reduction.

Reference [5] examines the relationship between foreign direct investments and gross fixed capital formation (GFCF). They discuss how the changes in FDI patterns over the years impact domestic economy components such as employment, productivity, the balance of payments, international trade, and 
GFCF. The article provides hypothesized links between FDI and GFCFs by exploring the motivation for the FDI.

Reference [6] examines the applicability of FDI as a valid indicator for transnational corporation (TNC) activities. It also provides definitions of FDI which are provided by two international organizations International Monetary Fund (IMF) and OECD and makes a clear distinction between portfolio investment and direct investment.

\section{BACKGROUND INFORMATION}

\section{A. Conceptual Knowledge of Foreign Direct Investments}

Foreign Direct Investment (FDI) is a financial process associated with companies operating and controlling income-generating facilities in at least one country outside their country of origin [1]. Foreign direct investment is expected have a lasting impact, rather than a temporary investment; FDI is a long-term type of investment and it has a weighty degree of influence by the foreign direct investor on the management of the enterprise.

Still, the description of FDI may vary in a few ways. First, FDI may be used simply to move a corporation into the status of MNC. Furthermore, FDI may be considered the process of a company investing capital internationally in order to acquire a factory or distributor. Statistically, FDI is the broad term used by official agencies to measure in monetary terms the yearly incoming and outgoing flow and the aggregate value of the stock of inward direct investments, on a country-by-country basis [1].

Generally, the foreign direct investment topic appears in the public domain at a relatively high level of generalization. Different kinds of FDI do exist. However, all of them share a commonality that companies must determine that the revenues will exceed the costs. The categories that FDI types can be classified as are: by objectives of/motivation for establishing a foreign subsidiary, by the role in the parent company's global production strategy, by method of financing a new subsidiary, and by extent of foreign ownership.

Several misconceptions related to foreign direct investments do exist. Many times FDIs are associated with MNCs or Portfolio Investment. However, portfolio investment occurs when an individual or financial institution buys a number of shares in a company located in another country with the expectation that those shares will appreciate in value and can be sold at a profit at a future time. In this case, the investor does not have influence over management decisions and long-term commitment to the company. Two categories of criteria are used for this distinction: the time horizon of the investment and the investor's incentive. If it is a short-term investment, and the investors primarily are investing funds only, the investment is categorized as portfolio investment [6].

\section{B. Opportunities for Foreign Direct Investment and Free Trade}

Foreign direct investments are an important key component in the global economy. The increase in FDIs started with the onset of free trade agreements such as NAFTA (North
American Free Trade Agreement), AFTA (Asian Free Trade Area), and the creation of EU (European Union). After the end of World War II and the onset of the Cold War, the United States became a proponent of establishing free trade and reducing tariff barriers. The World Trade Organization (WTO) is the primary international body that promotes free trade among countries by setting up the rules for international trade.

Free trade (trade without the undue interference of the government) increases production and efficiency as countries specialize in a particular industry by purchasing cheaper resources from different countries or invest in other countries by allocating resources there. Customers benefit from being consumers in an open market because of the variety of products available due to global competition. As the competition expands, so does the pressure for developing new products. Therefore, in order for companies to gain comparative advantage over competitors, they must invent something new. Countries that are part of the open market and exercise free trade may increase their income; countries that lifted their trade barriers showed significant economic growth compared to countries that restricted trade.

Since the 1990s, the business environment and the way companies do business have significantly changed. Globalization and liberalization of markets are a reality. As the market became saturated in domestic countries, companies saw the opportunity to expand their market shares overseas. Companies realize that they have to provide their consumers with quality products at a cheaper price than their competitors if they want to keep them. Foreign direct investments help companies keep up with the changing business world by giving the companies the opportunity to invest in other countries.

\section{Reasons to Invest in Foreign Countries}

Increasing a company's profits by investing in a foreign country is an incomplete and simple explanation for the myriad reasons behind the complex corporate decisions when establishing an overseas business. Since there are many different reasons why companies invest in foreign countries, it makes it difficult to form a single all-purpose model to explain this financial phenomenon. Profit maximization concept does not provide deep analytic insight into the various motives behind a process as complex as investing overseas. Many variables are associated with the multitude of MNCs operating in different industrial sectors, which follow different business strategies to invest in different host countries. It would not be feasible for a single reason to provide a meaningful, comprehensive answer as to why it is worthwhile and necessary to invest overseas.

In the beginning, theorists treated FDI as a non-differentiated international capital flow, which is the same as any other kind of cross-border money movement. In addition to that, MNCs were viewed as being just another variant of Capital Bridge. It was presumed that companies shifted funds from one country to another for the same reason as any bank or individual investor would: to get a higher rate in return than could be obtained in the home country. Stephen Hymer provided meaningful insight into the theoretical underpinnings of FDIs and MNCs with explanations on how 
these companies differ from purely domestic enterprises [7].

One of the basic reasons for FDI to be attractive is that through expansion overseas, companies can meet the persistent mandate from shareholders for growth. When the current domestic market is already saturated, companies start looking for ways to attract new customers. Because foreign countries provide a large number of potential customers, U.S. companies are willing to invest. The core dilemma of trying to satisfy demand with limited resources was not an issue until the twentieth century. Overcapacity and saturation put significant pressure on the countries. Expansion became the only feasible route for those companies.

Another reason is the achievement of the desired lower production cost. Investment in relatively low-cost labor countries creates efficient economic systems, which help companies reduce their production cost, resulting in the increase in the net profits. The "China price" concept impacts a lot of companies and it appears a significant incentive to engage in FDI. It occurs when an U.S. supplier of manufactured goods is warned by important customers that they will go elsewhere if the company fails to match the lower prices offered by China-based companies. Unable to do so in the high-wage countries, the most feasible alternative for the U.S. is to establish their own subsidiaries in the low-cost manufacturer countries. Also, the relatively relaxed government regulations are another reason for companies to invest in foreign countries. Some companies in the service sector, such as companies providing accounting, legal, advertising, and public relations services, began establishing a worldwide presence in the late 1970s, mainly in response to the overseas initiatives of their major clients. An ambitious overseas strategy is now considered common for companies desiring to be in the forefront of their markets.

\section{Timeline of Foreign Direct Investment - A Road from Obscurity to International Economic Powerhouse}

Foreign direct investments' timetable has a long evolutionary process. Historical data suggest that the larger political, technological, and economic environments mainly influenced the nature and timetable of that process. However, the past two decades indicated a significant increase in the foreign direct investment inflows. In a fifteen-year period, 1990 to 2005, global FDI inflows experienced a huge growth: $\$ 203$ billion to $\$ 974$ billion. Middle income countries are experiencing an increasing share with net FDI inflows in the gross domestic product (GDP) rising from $0.74 \%$ in the $1970 \mathrm{~s}$ to $1.08 \%$ between 1985 and 1994 , and to $2.85 \%$ between 1995 and 2005 [2].

If traced back in history, the origin of the FDI and MNC can be considered as far back as the seventeenth century. The colonization and large-scale expansions of trade and human migration outside of the European Continent gave the birth of the first multi-country business enterprises. The British East India Company and the Dutch East India Company are examples of the first seventeenth century trading companies. The transition to the contemporary version of MNC was underway in the second half of the nineteenth century. However, the beginning of 1960s saw a perfect combination of forces that generated significant increases in FDI and MNCs. In 1970 the estimated number of MNCs was 7,000, which increased to 30,000 by 1990, and 77,000 in 2005 [1].

\section{E. Effects on Society in Developed Versus Developing Countries}

U.S. companies invest in both developed and developing countries. If a company's primary purpose is the use of a firm's existing technological and organizational assets and capabilities, it is seen as asset-exploiting. The opposite, asset-augmenting, is where a company uses FDI in an effort to expand its technological and other tactical resources. Companies are looking for countries with both a sophisticated infrastructure and the ability to find employees with specialized skillsets [8]. FDI generates benefits for developing countries by giving them the opportunity to gain productivity and knowledge advantages. However, the impact of FDI on economic productivity growth is much stronger in developed economies than in less developed economies [4].

\section{F. Advantages of FDI}

Benefits are generated by FDIs in the form of higher employment, exports, additional tax revenue, and the knowledge and technology that will pass to domestic firms, thus promoting economic growth [9]. Spillovers, if they exist, can have a greater impact on the host country's economy, as follows:

- The higher the amount of linkage (including competition) between foreign MNCs and domestic firms;

- The greater the alignment of MNCs to the local market and;

- The higher the level of the host country's competence and the technological savvy for domestic firms to effectively adapt the spilled knowledge [10].

In almost all instances, FDI had an essentially positive impact on productivity [10]. Advantages of FDIs, when compared to other sorts of capital inflows, include the inherent longer-term positioning, which leads to stability [11]. Also FDIs provide a greater likelihood of increasing the level of aggregate investment and economic development in the host country [12].

\section{DATA AND RESEARCH METHODOLOGY}

Over the years, the U.S. has shown a significant interest in investing in other countries. Some European countries have benefited from the large amount of U.S foreign direct investment outflows. Also, a significant increase in the average amount of FDI outflows for the past ten years (2000-2008) can be observed compared to the average outflows for the previous 10-year period (1990-1999).

A comprehensive econometric model will be tested with the following variables and hypothesis:

$$
\begin{gathered}
\mathrm{PFDI}=\beta_{0}+\beta_{1}(\mathrm{GDP})+\beta_{2}(\mathrm{CGDP})+\beta_{3}(\mathrm{RER})+\beta_{4}\left(\mathrm{~TB}_{-1}\right)+ \\
\beta_{5}(\mathrm{USEM})+\varepsilon t .
\end{gathered}
$$

- PFDI is the dependent variable which measures the U.S (home country) foreign investment and GDP ratio of the host country. The independent variables capture some demand and supply determinants of the U.S. investment 
in host country and home country.

- GDP = GDP in dollars that measures the market size of host country which is expected to be positive.

- $\quad \mathrm{CGDP}=$ Annual real growth rate of GDP that measures the growth rate of market size of the host country which is expected to be positive.

- $\quad \mathrm{TB}_{-1}=$ Trade balance of the host country measured in U.S. dollars which is equal to the total export minus total imports lagged one year and it is expected to have an ambiguous sign.

- RER = Real exchange rate which measures the real exchange rate of domestic currency in terms of U.S. dollar; it is expected to have a negative sign. It is the average rate at year end.

- USEM = U.S unemployment rate (proxy for business cycle) which is expected to have a negative sign.

- $\varepsilon t=$ Stochastic disturbance term, is assumed to be white noise [13].

The test is conducted to examine the model for the entire observation period (1990-2008). Any serial correlation or auto correlation will be corrected and the model should provide a good indication of the variables that are significant determinants of the U.S. FDI in these countries. Following this regression test for all countries, the study will also look at the trends of U.S. FDI into these countries. This is done by looking at the mean and the percentage change of FDI over time. The data will be collected from secondary sources for the period 1990-2008 [14], [15].

\section{EMPRIRICAL RESULTS}

The regression results are shown in Table I. Table I provides the estimated values of the coefficients and their corresponding t-statistics using the Ordinary Least Square (OLS) tests for the entire testing period (1991-2008). The OLS estimation has estimated coefficients that are correct in some cases but less so in others. Similarly some of them are significant, while others are not.

Major countries which are part of the EU are studied because they are expected to be of great interest for U.S. foreign direct investments. The chosen countries include France, Germany, Spain, The Netherlands, and The United Kingdom.

TABLE I: REGRESSION ANALYSIS OF THE DETERMINANT OF U.S. FDI IN EUROPEAN COUNTRIES

\begin{tabular}{lccccc}
\hline \hline Coefficient & France & Germany & Spain & Netherlands & The UK \\
\hline Constant & -2983.01 & 117.65 & 1080.68 & 21257.32 & -4754.34 \\
& $(.099)^{+}$ & $(.815)$ & $(.043)^{*}$ & $(.596)$ & $(.001)^{+}$ \\
\hline GDP & -0.07 & -0.13 & -0.003 & -23.04 & 6.15 \\
& $(.000)^{+}$ & $(.006)^{+}$ & $(.119)$ & $(.143)$ & $(.000)^{+}$ \\
\hline CGDP & 0.05 & 0.09 & 0.003 & 19.34 & -0.42 \\
& $(.011)^{*}$ & $(.118)$ & $(.247)$ & $(.131)$ & $(.912)$ \\
\hline RER & 43.76 & 5.81 & -10.62 & -247.50 & 30.85 \\
& $(.001)^{+}$ & $(.130)$ & $(.285)$ & $(.634)$ & $(.004)^{+}$ \\
\hline TB-1 & -0.28 & 3.50 & -0.01 & 0.55 & -5.15 \\
& $(.880)$ & $(.000)^{+}$ & $(.001)^{+}$ & $(.001)^{+}$ & $(.010)^{+}$ \\
\hline USEM & -58.24 & 11.34 & 37.91 & 1583.92 & -160.42 \\
& $(.084)$ & $(.742)$ & $(.698)$ & $(.306)$ & $(.026)^{*}$ \\
\hline$R^{2}$ & .09099 & .9497 & .8951 & .852 & .9936 \\
\hline Adjusted $R^{2}$ & .8724 & .9288 & .8514 & .7903 & .9909 \\
\hline F-Statistic & 24.24 & 45.35 & 20.48 & 13.82 & 373.11 \\
& $(.000)^{+}$ & $(.000)^{+}$ & $(.000)^{+}$ & $(.001)^{+}$ & $(.000)^{+}$ \\
\hline \hline +significant at 1 percent level & & & & \\
$*$ significant at 5 percent level & & & &
\end{tabular}

In the case of France, only the CGDP has the correct coefficient and is significant at one percent level. The only other variable that is significant at the one percent level and does not have the correct coefficient sign is GDP. The rest of the variables are not significant and some of them do not have the correct coefficients. For Germany, the only variables that have the correct coefficient sign and are significant at one percent level are GDP and $\mathrm{TB}_{-1}$. However, the only variable that is significant at one percent level, but has incorrect theoretical sign, is the CGDP. However, it does not have the correct coefficient sign and therefore it is not under consideration for this analysis. For Spain and The Netherlands, only $\mathrm{TB}_{-1}$ has the correct coefficient, a negative sign for Spain and a positive sign for The Netherlands. Both variables are significant at one percent level. For the United Kingdom, the only variables that are significant and have the correct coefficient are GDP, RER, TB ${ }_{-1}$, and USEM. Both
CGDP and $\mathrm{TB}_{-1}$ are significant at one percent level, while USEM is significant at five percent level. The trade balance has a negative sign, which means that it experienced a deficit for the past twenty years.

Table I also shows that estimated adjusted $R^{2}$ is quite high for all five countries, especially Germany. This means that these four regression equations are good fits for these countries' economies, with the exception of the U.K. where the Adjusted $\mathrm{R}^{2}$ is too high. For the other four countries, the F-statistics are significant at one percent level, which implies that these independent variables explain the dependent variable and its impact on the economy.

\section{DISCUSSION AND ANALYSIS}

The empirical results of this region yielded some interesting results. It is safe to say that in the European region, 
the GDP was significant for three countries, although it had incorrect sign for both. But the F-statistics indicated that the model was a good fit for all five countries. These results are quite similar to the findings of the Asian countries [16]. In some way, the model in general can be considered appropriate. However, some of the independent variables are not well explained by the regression model. Hence, given these results it is not possible to make many general conclusions based on the results.

\section{SUMMARY AND CONCLUSION}

The scope of this study was limited to the U.S. FDI and only five countries with the intent to gather some perspective of U.S. FDI in this region. To that extent, the study indicated the econometric model did well to a point, even though the results were not too impressive, although most of the F-statistics were significant. Therefore, this study is considered just the first step but in the right direction.

Future studies must extend this study from several angles. More countries within different blocs around the world should be analyzed. The additional independent variable should be looked into, including the dummy variable to denote a tax holiday, or association to regional group or bloc like ASEAN, EU, or NAFTA. These additional variables may shed some new insight on U.S. FDI in these countries and for these regions in general.

Also, given the changes that has taken place in recent years (including the 2008-2009 global financial crisis and the Eurozone debt crisis, it would be very interesting to how these events have influence U.S. FDI into these countries as well as other EU countries.

\section{REFERENCES}

[1] S. Cohen. (May 2007). Multinational corporations and foreign direct investment: Avoiding simplicity, embracing complexity. Oxford Scholarship Online. [Online]. Available: http://www.oxfordscholarship.com/view/10.1093/acprof:oso/9780195 179354.001.0001/acprof-9780195179354

[2] S. Seyak, "Foreign direct investment and inflation," Southern Economic Journal, vol. 76, no. 2, pp. 419-443, October 2009.

[3] M. M. Ruane, "Attracting foreign direct investments: challenges and opportunities for smaller host economies," Journal of International Business Research, vol. 7, pp. 65-74, 2008.

[4] M. Yamin and R. Sinkovics, "Infrastructure or foreign direct investment? An examination of the implications of MNE strategy for economic development," Journal of World Business, vol. 44, no. 2, pp. 144-157, 2009.
[5] W. Hejazi and P. Pauly, "Motivations for FDI and domestic capital formation," Journal of International Business Studies, vol. 34, no. 3, pp. 282-309, 2003.

[6] M. Stephan and E. Pfaffmann, "Detecting the pitfalls of data on foreign direct investment: Scope and limits of FDI data," Management International Review, vol. 41, no. 2, pp. 189-218, 2001.

[7] S. H. Hymer, The International Operations of National Firms: A Study of Direct Foreign Investment, Cambridge, Mass: MIT Press, 1976.

[8] J. H. Dunning and R. Narula, Multinationals and Industrial Competitiveness: A New Agenda, Cheltenham: Edward Elgar Publishing, 2004.

[9] M. Blomstrom and A. Kokko, "The economics of foreign direct investment incentives," Kiel Institute for the World Economic Working Paper 168, January 2003.

[10] J. Morisset and N. Pirnia, "How tax policy and incentives affect foreign direct investment: A review," Foreign Investment Advisory Service Occasional Paper 15, 2001.

[11] V. Palmade and A. Anayitas. "Public policy for the private sector 273," FDI Trends, September 2004.

[12] P. Nunnenkamp, "Foreign direct investment in developing countries: What policymakers should not do and what economics don't know," Kiel Institute for the World Economic Discussion Paper 380, July 2001.

[13] B. Maniam, S. S. Metha, and J. B. Bexley, "Determinants of U.S. and Japanese foreign direct investment in China: An empirical investigation," Journal of Accounting \& Finance Research, vol. 8, no. 5, pp. 17-29, 2000.

[14] Bureau of Economic Analysis. (2005-2008). [Online]. Available: www.bea.gov

[15] L. Tsurkanu and B. Maniam, "An empirical investigation of U.S. foreign direct investments in Asia," Review of Business Research, vol. 10, no. 4, pp. 149-153, 2010.

[16] Survey of Current Business, U.S. Department of Commerce, 1990-2005.

Lidiya Tsurkanu was an honors student and she obtained her degree from Sam Houston State University. Her research interests include corporate finance and international finance, she has work on several articles in these areas.

Hadley Leavell is a professor of finance at Sam Houston State University, Texas, USA. He obtained his DBA degree from Louisiana Tech University. He has published many peer-reviewed journals in the area of finance and international business. He also have presented in many national and international conferences. He also serves in the editorial board of the Journal of International Business Research.

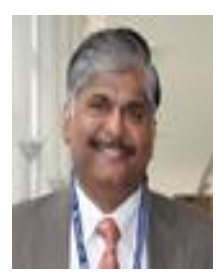

Balasundram Maniam is a regents' professor of Finance and Minnie Stevens Piper Professor at Sam Houston State University, Texas, USA. He obtained his Ph.D. degree from University of Mississippi in 1992. He has published over 150 peer-reviewed journals and presented over 250 international and national conferences. He was also the recipient of Excellence in Research and Excellence in Teaching awards at Sam Houston State University in 2003 and 2008 respectively. He also serves as an editor and co-editor of journals and serves in editorial boards of several journals. 